\title{
Policing Corruption Post- and Pre-crime Collective Action and Private Authority in the Maritime Industry
}

\author{
Krause Hansen, Hans
}

Document Version

Final published version

Published in:

Indiana Journal of Global Legal Studies

DOI:

10.2979/indjglolegstu.25.1.0131

Publication date:

2018

License

Unspecified

Citation for published version (APA):

Krause Hansen, H. (2018). Policing Corruption Post- and Pre-crime: Collective Action and Private Authority in the Maritime Industry. Indiana Journal of Global Legal Studies, 25(1), 131-156.

https://doi.org/10.2979/indjglolegstu.25.1.0131

Link to publication in CBS Research Portal

\section{General rights}

Copyright and moral rights for the publications made accessible in the public portal are retained by the authors and/or other copyright owners and it is a condition of accessing publications that users recognise and abide by the legal requirements associated with these rights.

Take down policy

If you believe that this document breaches copyright please contact us (research.lib@cbs.dk) providing details, and we will remove access to the work immediately and investigate your claim. 


\title{
Policing Corruption Post- and Pre-crime: Collective Action and Private Authority in the Maritime Industry
}

\section{Hans Krause Hansen}

\author{
Journal article (Publisher's version)
}

\section{Please cite this article as:}

Krause Hansen, H. (2018). Policing Corruption Post- and Pre-crime: Collective Action and Private Authority in the Maritime Industry. Indiana Journal of Global Legal Studies, 25(1), 131-156. D0I:

10.2979/indjglolegstu.25.1.0131

\section{DOI: 10.2979/indjglolegstu.25.1.0131}

No part of this document may be reproduced, stored in a retrieval system, transmitted, or distributed in any form, by any means, electronic, mechanical, photographic, or otherwise, without the prior permission of Indiana University Press. For educational reuse, please contact the Copyright Clearance Center

http://www.copyright.com/. For all other permissions, contact IU Press at http://iupress.indiana.edu/rights/.

Uploaded to CBS Research Portal: May २०19

With permission by Indiana University Press 


\title{
Policing Corruption Post- and Pre-Crime: Collective Action and Private Authority in the Maritime Industry
}

\author{
HANS KRAUSE HANSEN*
}

\begin{abstract}
How are we to understand the proliferating attempts amongst transnational corporations (TNCs) at collectively reducing the risk of corruption in business operations and interactions with state officials around the world? How are these endeavors linked to transformations of public and private authority in the global political economy? Premised on the observation that corruption is globalized and the growing efforts at tackling it equally so, this article draws on the literatures on private authority, governmentality, and criminological studies to explore anticorruption in terms of pre-crime and post-crime policing. The case of the maritime industry is analyzed, including the ways in which corruption is policed post-crime by governments and pre-crime by a collective action initiative, the Maritime Anti-Corruption Network (MACN). The paper finally discusses how the incipient collective policing of corruption undertaken by corporations nowadays intersects with changes in the organization of public and private authority. Corporate policing of corruption does not imply a simple shift from public toward private authority, but rather a growing emphasis on pre-crime interventions in a largely disaggregated, polycentric, and liquid global governance set-up, with corporations and their collective action initiatives emphasizing anticipatory logics and attempts at forestalling corruption.
\end{abstract}

\section{INTRODUCTION}

On August 5, 2013, the Lagos-based website Ships \& Ports...the voice of the maritime industry published a news article entitled

* Hans Krause Hansen is a professor of governance and cultural studies at Copenhagen Business School.

Indiana Journal of Global Legal Studies Vol. 25 \#1 (Spring 2018)

(c) Indiana University Maurer School of Law 
"Corruption Risk Assessment Report throws ports into panic."1 While hinting at the intricate nature of corruption in Nigerian ports, the article describes how suspected port and customs personnel went into hiding in neighboring West African countries as a result of revelations made in the mentioned report. ${ }^{2}$ Originally commissioned by the Nigerian government authorities with the participation of the United Nations Development Program (UNDP) and the business-driven Maritime Anti-Corruption Network (MACN), the report contained an assessment of the "corruption risks" faced by transnational corporations (TNCs) operating in Nigerian ports, as well as solutions to the problem, including the collective anti-corruption mobilization of TNCs. ${ }^{3}$

This short glimpse from Nigeria provides an example of the contemporary globalization of corruption and anti-corruption. Rather than being bounded within national territories exclusively located in developing countries like early research on corruption suggested, most corrupt practices are in fact networked, mediated, and trans-local, with effects on economic and political activities at multiple levels and across boundaries. ${ }^{4}$ The organized fight against corruption similarly has come to have a transnational character, driven in large part by formal legislation and criminalization on a global scale, ${ }^{5}$ and more recently by corporate engagement on an individual and collective basis. ${ }^{6}$ German multinational giant Siemens AG illustrates the intersection of criminalization and corporate engagement. For years, the company and

1. See SHIPS \& PORTS, Corruption Risk Assessment Report throws ports into panic (Aug. 5, 2013), http://shipsandports.com.ng/corruption-risk-assessment-report-throwsports-into-panic.

2. See Bureau of Public Procurement, Independent Corrupt Practices and

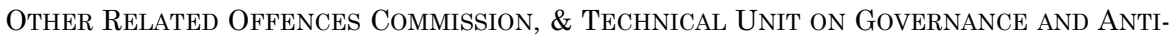
CORRuption, Report of CORRUPtion Risk Assessment In the PORTS SECTOR IN NigERIA (Aug. 2013), http://tugar.org.ng//wp-content/uploads/2016/01/Report-of-Corruption-RiskAssessment-in-the-Ports-Sector.pdf (Nigeria).

3. Where the increasing pressures on businesses to act against corruption are recognized: "International companies of today are obligated to take an active stand against corruption. Bribery and corruption regulation is ever-tightening. Additionally, stakeholders such as governments, international institutions and non-governmental organizations expect companies to play a significant role in addressing the root causes of corruption." Id. at 5.

4. See Luís de Sousa, Peter Larmour \& Barry Hindess, Introduction to Governments, NGOs AND ANTI-CORRUPtION: THE NEW INTEGRITY WARRIORS, 1, 5-8 (Luís de Sousa, Peter Larmour \& Barry Hindess eds., 2009); Alexander Cooley and J. C. Sharman, Transnational Corruption and the Globalized Individual, 15 PERSP. ON POL. 732, 733-35 (2017).

5. See Philip M. Nichols, The Business Case for Complying with Bribery Laws, 49 AM. Bus. L.J. 325, 365-66 (2012).

6. See Mark Pieth, Collective Action and Corruption, in ColleCtive ACTION: InNovative Strategies to PREvent CoRruPtion 3 (Mark Pieth ed., 2012). 
some of its subsidiaries had routinely paid bribes to win contracts around the world. ${ }^{7}$ Following legal sanctions in 2008, it developed comprehensive compliance programs, and in collaboration with international organizations, NGOs, and other TNCs, it got involved in collective initiatives aimed to set new standards for anti-corruption throughout its value chains. ${ }^{8}$

This article sets out to analyze in more detail the emergence and operations of corporate collective action initiatives against corruption, and it speculates about their implications for the organization and transformations of public and private authority in the global political economy. Collective anti-corruption action initiatives are heterogeneous in composition, but TNCs play an increasingly important role in them. This observation leads to the question why individual corporations create and engage in collective action initiatives, something scholars have investigated in relation to safety, labor, and environmental matters. ${ }^{9}$ By forming "clubs," companies can share knowledge about problematic challenges. They can monitor and certify acceptable organizational practices within a specific area, which can incentivize other parties to join in, potentially ratcheting up standards. Much of this research focuses on the formal economic logic of collective action and derives explanations from economic "rational choice" dilemmas. The approach has more recently been applied to collective action in anticorruption. Individual companies may want to avoid paying bribes when acting in markets where corruption is the norm. Still, they keep on bribing because if they abstain, their equally bribe-paying competitors will have a competitive advantage. But everyone would be better off without paying bribes, which is why there is a strong "business case" for collective action against it: With companies agreeing collectively on mutually beneficial anti-corruption rules and practices, the dilemma faced by individual companies would ultimately be overcome. ${ }^{10}$ By

7. See Press Release, U.S. Dep't of Justice, Siemens AG and Three Subsidiaries Plead Guilty to Foreign Corrupt Practices Act Violations and Agree to Pay $\$ 450$ Million in Combined Criminal Fines (Dec. 15, 2008), https://www.justice.gov/archive/opa/pr/2008 /December/08-crm-1105.html.

8. See, e.g., Karl Sidhu, Anti-Corruption Compliance Standards in the Aftermath of the Siemens Scandal, 10 GER. L.J. 1343 (2009); Sabine Zindera \& Birgit Forstnig-Errath, Siemens: Promoting Collective Action-From Theory to Action, in Collective ACTION: InNOVATIVE STRATEGIES TO PREVENT CORRUPtion 177 (Mark Pieth ed., 2012).

9. See, e.g., Elizabeth DeSombre, Flagging Standards: Globalization And ENVIRONMENTAL, SAFETy, AND LABOR REgulations AT SEA (2006); Voluntary Programs: A Club Theory Perspective (Matthew Potoski \& Aseem Prakash eds., 2009); Tim Bartley, Standards for Sweatshops: The Power and Limits of the Club Approach to Voluntary Labor Standards, in VOLUnTARY PROGRAMS: A Club THEORY PERSPECTIVE 107 (2009).

10. See, e.g., Pieth, supra note 6. 
putting the analytical focus squarely on the resolution of collective action dilemmas based on the assumption of rational choice, such approaches risk overlooking significant contextual and institutional dynamics facing corporations as they engage with multiple actors in highly different environments. Such dynamics include the interactions between state agencies, corporations, and other non-state actors operating at different levels; the changing responsibilities for intervention in corruption (state or corporate); and the temporal modes in anti-corruption practices, such as backward-oriented punishment for legal violations and future-oriented prevention cast in the language of corruption risk.

This article builds on insights from theories of private authority, studies of governmentality, and criminological studies to consider these dynamics more thoroughly. My focus is on the maritime industry, and more specifically, on the above-mentioned business-driven Maritime Anti-Corruption Network (MACN), which operates transnationally and targets not only fellow industry actors but also public agencies in national and local contexts such as ports and customs where corruption is commonplace, if not endemic. Following a discussion of some of the strengths and weaknesses of the literature on private authority, I argue that the rise of collective corporate action against corruption, rather than considered a rise of private authority per se, is better understood as an extension of public authority into the corporate sector. More importantly, I challenge the rather crude distinction between public and private authority and argue that a focus on the multiple governmental rationalities, techniques, and practices that go into the policing of corruption provides a more nuanced understanding of the character and possible implications of corporate collective action initiatives. I demonstrate that policing is being diversified, pluralized, and temporarily configured, with states mostly undertaking reactive measures post-crime, while companies and other non-state actors are becoming more insistent on proactively forestalling corruption precrime. The policing of corruption also entails an increasing focus on corruption risks, whose conditions are sought to be addressed proactively in global supply chains and the larger business environment. This especially includes regions where state institutions are not consolidated.

The emergence of corporate collective action initiatives suggests an interesting change in the general perception of corporations. While always considered a source of corruption, the private sector has become part of and even staged as the driver of anti-corruption. While this activity implies a critique of corruption, it certainly does not involve a critique of capitalism. Rather, it problematizes corruption as a set of 
practices distorting markets, fair competition, and economic development, which poses a risk to business operations. Corporate anticorruption rests solidly on the grounds of the market economy and is contingent upon as well as fuels a vibrant anti-corruption industry, which, largely on a commercial basis, produces and delivers the standards, technologies, accounting, and legal advice needed in the fight against corruption. ${ }^{11}$ Even though this development suggests that corporate anti-corruption has become a globally accepted norm, there is still little, if any evidence at all, of its effectiveness in reducing corruption risks for corporations, and unsurprisingly perhaps, that anticorruption efforts reduce the existence of corrupt practices more generally. But it shows that states have become more visible in the conduct of corporations regarding corruption control, and also that corporations in turn seek to make visible their law commitment and efforts to shape the business environment accordingly.

This article points to the important role of corporate collective action initiatives in this regard, and it is organized as follows: Section I discusses key insights on private authority, studies of governmentality, and criminology. Section II focuses on the governance of the maritime industry, whereas section III discusses important aspects of corruption and anti-corruption interventions by governments post-crime in the maritime arena. A more detailed study of a corporate collective action initiative against corruption in the maritime industry, MACN, which is shown to operate pre-crime, is undertaken in section IV. Section V finally revisits insights from research on private authority and related concepts to discuss how the policing of corruption undertaken by corporations nowadays intersects with changes in the organization of public and private authority.

\section{Transnational Private Authority and the Policing OF CORRUPTION}

In Private Authority in International Affairs, Cutler, Haufler, and Porter analyzed the role of corporations in the development of transnational private authority rising from inter-firm cooperation and

11. See Steven Sampson, The Anti-corruption Industry: From Movement to Institution, 11 Global CRIMe 261, 262 (2010); see also Mike Koehler, A Common Language to Remedy Distorted Foreign Corrupt Practices Act Enforcement Statistics, 68 RuTGERS U. L. REV. 553, 558 (2016); see generally Hans Krause Hansen, Managing Corruption Risks, 18 REV. INT'L POL. ECON. 251 (2011) (investigating the engagement of Western corporations in international anti-corruption); Rieneke Slager, The Discursive Construction of Corruption Risk, 26 J. MGMT. INQUIRY 366 (2017) (examining how accountants construct the concept of anti-corruption risk in discourse aimed at private sector audiences). 
standards. ${ }^{12}$ Legitimate authority needs not be associated with the state. In fact, it can be associated with corporations, which "can become authoritative or government-like, even in the international sphere, thus challenging our notions of the character of political authority itself." 13

Hall and Biersteker extended the focus on private authority to include transnational religious movements, NGOs, and transnational criminal organizations (TCOs). ${ }^{14}$ Building on this framework, Williams explored the phenomenon of illicit private authority, which echoed conceptions of Weberian authority beyond the legal-rational, such as traditional and charismatic forms. Where public authorities are unable to provide public goods, TCOs could take over this function. Operating as de facto governments providing public goods, TCOs can earn social acceptance and legitimacy through recognition and consent of the populace, even though brute force and corruption represent their main instrument of influence and governance. ${ }^{15}$ TCOs mobilize illicit private authority through petty and grand corruption. Such corruption can range from small-scale bribery and extortion in the streets and at borders to outright policy and state capture by kleptocrats, with huge transfers of money, services, and other subtle transactions between these and drug lords. ${ }^{16}$

These observations on private authority, illicit or not, resonate with conceptualizations such as "governance without government" 17 in "areas of limited statehood." 18 The latter concept especially offers a different perspective on the governance of what has commonly been termed "failed," "fragile" or "weak states." Areas of limited statehood refer to territorial entities, policy fields, and/or social groups, for which the state cannot maintain a monopoly of force, and where it is facing significant challenges in terms of rule implementation and enforcement. Limited statehood, be it in a specific region; in sectors like health, education or security; or regarding a particular population group, does not imply that

12. See Private AUthority And International AfFairs 3 (A. Claire Cutler et al. eds., 1999).

13. A. Claire Cutler et al., Private Authority and International Affairs, in PRIVATE AUthority AND InTERnATIONAL AFFAIRs 3, 6 (A. Claire Cutler et al. eds., 1999).

14. See The Emergence of Private Authority In Global Governance 9-18 (Rodney Bruce Hall \& Thomas J. Biersteker eds., 2002).

15. See Phil Williams, Transnational Organized Crime and the State, in THE EMERGEnCE of PRIVATE AUTHORITY IN Global Governance 161, 171 (Rodney Bruce Hall \& Thomas J. Biersteker eds., 2002).

16. Id. at 175 .

17. See generally Governance Without Government: ORDER AND CHANGE IN WorLD Politics (James N. Rosenau \& Ernst-Otto Czempiel eds., 1992) (clarifying the nature of global order and the process through which governance occurs on a worldwide scale).

18. See Governance Without a State?: Policies and Politics in Areas of Limited STATEHOOD 9-12 (Thomas Risse ed., 2011). 
governance is absent. Non-state actors can carry out governance tasks in the relative absence of functioning national government agencies. This may include TCOs potentially gaining illicit private authority by filling out the voids left by a dysfunctional state. ${ }^{19}$

In this article, my primary focus is not on TCOs but "licit" TNCs operating transnationally, especially their growing focus on anticorruption work. Of course, TNCs can, and often do, resort to various forms of corruption in their business activities and transnational networks. This can link them, directly or indirectly, to TCOs. But contrary to TCOs, whose core financial activities are mostly clandestine, TNCs are legally recognized entities that have to earn and maintain their legal "license to operate." They are formally targeted by national and transnational regulations that, over the past few decades, have come to include requirements to abstain from and prevent the use of bribery in business transactions. ${ }^{20}$ This also highlights TNCs' potentially important role in struggles against corruption in areas of limited statehood. Where the state is not consolidated, TNCs, like international organizations and NGOs, can in principle serve as "functional equivalents." But such a situation does not easily translate into TNCs having legitimate private authority as described above. Legitimate authority, public or private, ideally implies two layers of recognition. The first involves the recognition that an authority is considered per se functionally necessary in order to achieve public goods. The second layer implies that actors recognize that authority as legitimate (i.e., aligned with the norms and beliefs of a community). ${ }^{21}$ From this lens, therefore, collective anti-corruption initiatives may operate as "functional equivalents" for statehood (i.e., providing the public good of corruption control in some form or another because the state is unable to do it) but are not necessarily legitimate in the eyes of the local population in question.

Other recent scholarship ${ }^{22}$ has set out to nuance the rather crude distinction between public and private authority, including its

19. Williams, supra note 15; see also Christopher Marc Lilyblad, Illicit Authority and Its Competitors: The Constitution of Governance in Territories of Limited Statehood, 2 TERRITORY POL. GOVERNANCE 72 (2014).

20. See Larry Catá Backer, Multinational Corporations as Objects and Sources of Transnational Regulation, 14 ILSA J. INT'L \& COMP. L. 499, 523 (2008).

21. See Tanja A. Börzel \& Thomas Risse, Governance Without a State: Can It Work?, 4 REG. \& Governance 113, 127 (2010); Michael Zürn, Martin Binder \& Matthias EckerEhrhardt, International Authority and its Politicization, 4 INT'L THEORY 69, 82-88 (2012); PRIVATE AUTHORITY AND INTERNATIONAL AFFAIRS, supra note 12; Williams, supra note 15.

22. See, e.g., Hans Krause Hansen \& DorTe SAlskov-Iversen, Critical Perspectives on Private Authority in Global Politics (Hans Krause Hansen \& Dorte Salskov-Iversen eds., 2008); Kenneth W. Abbott \& Duncan Snidal, Strengthening 
associated vocabulary of legitimacy and consent, and to highlight instead the rise of new forms of interdependence and interaction between state and non-state actors. Ruggie, for example, argued that TNCs "have created a new transnational world of transaction flows that did not exist previously," and as a result they have implemented "novel management systems for themselves and for relations with their subsidiaries, suppliers, and distributors that they deem necessary given the scope, pace, and complexity of operating in those transactional spaces." 23 TNCs continue to depend on traditional legal mechanisms to protect their property rights and license to operate, which is why generalizing claims about a "shift" toward private authority remains problematic. The state remains central for the private sector, but in new, interdependent and interactive ways as TNCs expand their reach. ${ }^{24}$ Others have similarly emphasized the interaction between the public and private by problematizing the analytical treatment of them as separate realms. For instance, while the proliferation of accounting standards, fair trade labels, forestry certification schemes, labor rights monitoring, and transparency standards clearly suggests that "transnational business governance" (TBG) has grown in scope and importance as production and consumption globalize, such TBG schemes "do not operate in isolation. Rather, they interact with one another, and with state-based regimes, in diverse ways." 25

A glance at the emerging collective anti-corruption initiatives provides an interesting illustration of these interactive forms of interdependence. The initiatives are often mixed in composition because they are formally launched under the auspices of governments, international organizations, and NGOs or, as we shall see, by businesses alone. For example, the anti-corruption initiatives taken by the UNDP Global Anti-Corruption Initiative, the Extractives Industry Transparency Initiative (EITI), and the UN Global Compact are based in the state, but still count on support from private business. In contrast, initiatives like Partnering Against Corruption Initiative (PACI) under the World Economic Forum and the Maritime AntiCorruption Network (MACN) are distinct organizational forms driven by business. Still, they cooperate closely with governments,

International Regulation Through Transnational New Governance: Overcoming the Orchestration Deficit, 42 VANDERBILT J. TRANSNAT'L L. 501 (2009); Peer Zumbansen, Neither 'Public' nor 'Private', 'National' nor 'International': Transnational Corporate Governance from a Legal Pluralist Perspective, 38 J.L. \& SoC'Y 50 (2011).

23. John Gerard Ruggie, Reconstituting the Global Public Domain - Issues, Actors, and Practices, 10 EUR. J. INT'L. REL. 499, 503 (2004).

24. See id.

25. Burkard Eberlein et al., Transnational Business Governance Interactions: Conceptualization and Framework for Analysis, 8 REG. \& GOVERNANCE 1, 2 (2014). 
international organizations, and NGOs. ${ }^{26}$ Furthermore, all these initiatives have developed against the backdrop of state-driven efforts at criminalizing corruption over the past decades. Significant examples include the U.S. government's pioneered criminalization of corruption in an extraterritorial fashion through the Foreign Corrupt Practices Act of 1977 (FCPA), ${ }^{27}$ and the series of binding international conventions of the OECD and the U.N. during the 1990s and 2000s. ${ }^{28}$ Criminalization, with extraterritorial provisions, is today instituted by many national governments around the globe, and most recently with the UK Bribery Act of 2010.29 The importance of the U.S. government, World Bank, IMF, U.N. OECD, and Transparency International in enabling this development has been widely documented. ${ }^{30}$

Given the difficulty of conceptualizing corporate collective anticorruption initiatives in terms of private authority, it might be useful to consider the role and activities of these new arrangements by focusing on the practices they involve. Here, I shall propose the policing of corruption as a conceptual starting point. Policing refers conventionally to specialist public agencies that investigate potential violations of the rule of law, with the ultimate mandate to use force in the maintenance of social order broadly conceived. Here, I use the term in a broader sense. Policing can be carried out by a plurality of organizations-state, private and hybrids - that operate on assumptions that habits and activities envisaged and classified as problematic and potentially criminal (in this case as "corruption") must be anticipated and corrected. ${ }^{31}$ Insights from studies of governmentality provide a useful

26. See Hans Krause Hansen, Anti-Corruption Governance and Global Business, in Corporate Social Responsibility: Strategy, Communication, Governance 405-426 (Andreas Rasche, Mette Morsing \& Jeremy Moon eds., 2017).

27. See Foreign Corrupt Practices Act, U.S. DEP'T JUSTICE, https://www.justice.gov/ criminal-fraud/foreign-corrupt-practices-act (last updated Feb. 3, 2017).

28. See generally Philippa Webb, The United Nations Convention Against Corruption: Global Achievement or Missed Opportunity?, 8 J. INT'L ECON. L. 191 (2005) (considering the effectiveness of the U.N. Convention Against Corruption based on the first anticorruption initiatives it spawned).

29. Nichols, supra note 5, at 325, 352-67; Slager, supra note 11, at 369-70.

30. See, e.g., Peter Andreas \& Ethan Nadelmann, Policing the Globe: Criminalization AND CRime Control in International Relations (2006); ANJA P. JAKOBI, COMmOn GOODS AND Evils? THE Formation of Global CRIME GovernanCE (1st ed. 2013); Mlada Bukovansky, The Hollowness of Anti-corruption Discourse, 13 REV. INT'L POL. ECON. 181 (2006); Elizabeth Spahn, International Bribery: The Moral Imperialism Critiques, 18 MinN. J. INT'L L. 155 (2009); Sampson, supra note 11, at 261; Hansen, supra note 11 , at 251 .

31. David Garland, 'Governmentality' and the Problem of Crime: Foucault, Criminology, Sociology, 1 Theoretical Criminology 173 (1997); Conor O'Reilly, The Pluralization of High Policing: Convergence and Divergence at the Public-Private Interface, 55 Brit. J. CRiminology 688, 689 (2015); Carrie B. Sanders \& James Sheptycki, Policing, 
entry point to explore in more detail these new forms of policing in anticorruption, their division of labor, knowledge foundations, rationales and technologies, and governmental implications. ${ }^{32}$ This body of literature is diverse and generally skeptical of any a priori distinction between public and private authority, including the vocabulary of legitimacy. The analytical focus is not so much on the state as an institution but rather on governing practices, which emanate from a variety of sites and actors, ${ }^{33}$ including experts, non-governmental organizations, civic groups, companies, schools, and universities, and potentially even the aforementioned TCOs. All of these actors can potentially make up "centers of calculation" that "govern at a distance." There is a special analytical focus on the interface between knowledge and power, including the beliefs, justifications, and techniques through which individual or collective actors shape the conduct of others in institutionalized practices and in (trans-local) governance spaces not reducible to the state or the coordinates of the inter-state system.

In this "disaggregated," "polycentric," or "liquid" set-up, ${ }^{34}$ the state and its agencies can make a nodal point from which different government projects emerge, including laws and regulations. Laws and regulations are important, not as self-contained systems of thought or potential panacea, but because they problematize and provide justifications to act and intervene. As technical and tactical means of power, they can create social meaning and signification. Hence the production and coordination of social actors and their activities can at least partially be an effect of law. ${ }^{35}$ Still, the force of law and regulation

Crime and 'Big Data'; Towards a Critique of the Moral Economy of Stochastic Governance, 68 CRIME L. SOC. CHANGE 1 (2017).

32. See, e.g., Michel Foucault, Governmentality, in THE Foucault EFFECT: STUDIES IN GOVERNMENTALITY 87 (Graham Burchell et al. eds., 1991); MitCHELL DEAN, GOVERNMENTALITY: POWER AND RULE IN MODERN SOCIETY (1st ed. 1999); GLOBAL GOVERNMENTALITY: GOVERNING INTERNATIONAL SPACES (Wendy Larner \& William Walters eds., 2004); Peter Miller \& Nikolas Rose, Governing the Present: Administering ECONOMIC, SOCIAL AND PERSONAL LIFE (2008); Garland, supra note 31.

33. See, e.g., Garland, supra note 31 , at 175.

34. Hans Krause Hansen, Investigating the Disaggregation, Innovation, and Mediation of Authority in Global Politics, in CRITICAL PERSPECTIVES ON PRIVATE Authority IN Global Politics 4-5 (Hans Krause Hansen \& Dorte Salskov-Iversen eds., 2008). See generally Julia Black, Constructing and Contesting Legitimacy and Accountability in Polycentric Regulatory Regimes, 2 REG. \& GOVERNANCE 137 (2008) (arguing for greater attention to the dynamics of accountability and legitimacy relationships and to how those in regulatory regimes respond to them before new legitimacy and accountability regimes are created); see also Nico Krisch, Liquid Authority in Global Governance, 9 INT'L THEORY 237, 237-60 (2017).

35. See Nikolas M. Rajkovic, 'Global Law' and Governmentality: Reconceptualizing the 'Rule of Law' as Rule 'Through' Law, 18 EUR. J. INT'L REL. 29, 31 (2010); Matthias Goldmann, We Need to Cut Off the Head of the King: Past, Present, and Future Approaches 
is not reducible to the imposition of "sovereign will," which is the case when certain conduct is criminalized and violators are subject to disciplinary action under the auspices of the state. More than simply producing "discipline," the state and its laws can work to cultivate active and largely self-governing subjects that can align to governmental aims. Law can provide the occasion for actors and their networks to enroll into specific programs and projects, in which the law's particular meanings and significations are "translated" by actors from one domain or locale to another. This endeavor may be successful or not. Its outcomes are always shaped by the resistance or indifference of those acting in the networks. ${ }^{36}$

By mobilizing the language of laws and regulations, collective corporate initiatives in anti-corruption can take the form of organizations that potentially shape the conduct of business partners, competitors, and public officials. Internally, the members of a collective action initiative can decide to "agree on core elements or principles as well as (normally) a set of compliance-related prerequisites for membership." 37 Members can decide to allocate resources generated by membership fees and other funding; develop and share archives and databases providing knowledge about corruption, including its contextual dynamics and locations; and engage in the anti-corruption training of members and the monitoring of activity to ensure member compliance and internal reporting. In fact, collective initiatives may take shape of what Ahrne and Brunsson in ideal-typical terms call "complete or partial organizations," which vary regarding the completeness of organizational elements such as membership, hierarchy, rules, monitoring and sanctions. ${ }^{38}$ Externally, collective action initiatives can engage and cooperate with other social actors. The arrangements can enable action at a distance and across borders, shaping the management of supply chains down the line, the relations to public agencies, and so on.

Following this line of argument, what are the ways in which states and corporations have come to engage in the policing of corruption, if at

to International Soft Law, 25 LEIDEN J. INT'L. L. 335, 338, 366 (2012); Garland, supra note 31 , at $173,182-193$.

36. Miller \& Rose, supra note 32, at 33-34; John Braithwaite \& Peter Drahos, Global Business Regulation 482 (Cambridge Univ. Press ed., 2000); Gavin Kendall, Global Networks, International Networks, Actor Networks, in GLOBAL GoverNMENTALITY: GOVERNING INTERNATIONAL SPACES 59 (Wendy Larner \& William Walters eds., 2004).

37. Massimo Mantovani, The Business Case for Collective Action, in Collective ACtion: Innovative Strategies to Prevent Corruption 73, 76-79 (Mark Pieth ed., 2012).

38. See Göran Ahrne and Nils Brunsson, Organization Outside Organizations: The Significance of Partial Organization, 18 ORGANIZATION 83, 85-88 (2011). 
all? It is argued here that the techniques deployed by collective action initiatives driven by businesses are largely anticipatory, and more specifically "pre-crime." Whereas the concept of post-crime refers to reactive practices of crime control, including investigation, trial, and punishment, "pre-crime shifts the temporal perspective to anticipate and forestall that which has not yet occurred and may never do so." It involves "calculation, risk and uncertainty, surveillance, precaution, prudentialism, moral hazard, prevention and, arching over all these, there is the pursuit of security." 39 Post-crime is conventionally undertaken by state agencies, criminal justice, and the penal system, and it has crime scenes. Pre-crime, as epitomized by the counterterrorism laws implemented in most countries over the past fifteen years, pre-constructs hypothetical crimes and pre-enacts possible futures. While some fragile forecasts can always be made based on risk assessments, pre-crime essentially moves into the territory of uncertainty and the incalculable, opening up a space for predictions and pre-emptive action. Pre-crime operates with a heavy emphasis on imagination and prophesies. Still, it is frequently masked by the normalizing languages of science, algorithms, and the law and by the professional language of political and administrative agencies. One key dimension of pre-crime is the reliance on speculative intelligence, which is increasingly based on predictive algorithmic data mining, over more traditional probative evidence. ${ }^{40}$

With growing pre-crime, policing the responsibility for anticipating and forestalling risks and threats falls not only on the state but also on non-state actors. In areas of consolidated statehood, the state has traditionally been in charge of post-crime, but increasingly also of precrime activities, such as preventive policing, education, surveillance, algorithmic data mining, and profiling. ${ }^{41}$ In areas of limited statehood, post-crime interventions by national authorities, not least regarding corruption and bribery, have often been rudimentary if not corrupted or entirely absent. Given post-crime enforcement mechanisms at the national and international levels are generally weak, and since TNCs operate across boundaries, the responsibility for preventing criminal

39. Lucia Zedner, Pre-crime and Post-criminology?, 11 TheORETICAL CRIMINOLOGY 261, 262 (2007); see also Ben Anderson, Preemption, Precaution, Preparedness: Anticipatory Action and Future Geographies, 34 Progress HuM. GEOGRAPHY 777 (2010) (discussing how futures are anticipated and acted on in relation to a set of events that are taken to threaten liberal democracies).

40. See Jude McCulloch \& Dean Wilson, Precrime: Pre-emption, Precaution and THE FUTURE 29, 145 (2017).

41. See Lina Dencik, Arne Hintz \& Zoe Carey, Prediction, Pre-emption and Limits to Dissent: Social Media and Big Data Uses for Policing Protests in the United Kingdom, NEW MEDIA \& SOC'Y 1, 2 (2017). 
activities now extends to other actors, including corporations. Expected to carry out proper pre-crime work themselves, TNCs seek to demonstrate their self-governing capacities and align themselves to public laws and regulations in multiple jurisdictions, including in areas with weak law enforcement. More generally, we see here, as Ericson once put it, how law has come to intersect "with regimes of risk management, creating a public role for the state in the management of private organizations. Law makes risks and controversies about them public and visible." ${ }^{2} 2$ Likewise, the policing and internal controls set up by businesses to anticipate risks and uncertainties come to play a more visible public role. Not only are TNCs subject to media scrutiny, they also have to externalize and publicly justify their continuous construction of compliance and control arrangements in face of the uncertain. ${ }^{43}$ In other words, corporations have to publically demonstrate their commitment to the law and, increasingly, also to broader issues of corporate social responsibility and business ethics. ${ }^{44}$

The remainder of the article illustrates these points. Sections II and III provide a brief outline of maritime industry governance, discuss the problem of corruption, and identify the key characteristics of post-crime interventions by state actors. Section IV explores how the collective action initiative MACN addresses corruption including its pre-crime policing efforts in "hot spot" localities in areas of limited statehood, and is followed by a concluding section that discusses how corporate policing of corruption intersects with changes in the organization of public and private authority.

\section{GOVERNING THE MARITIME INDUSTRY}

The maritime industry is the world's oldest transnational business and constitutes the key infrastructure for the global movement of goods and services. More than 80 percent of global trade by weight and 70 percent by value are transported by ships moving between ports. ${ }^{45}$ Maritime industry actors are in constant clinch with political and administrative bodies across multiple jurisdictions, suggesting

42. RichaRd V. ERICSON, CRIME IN AN INSECURE WORLD 17-18 (2007).

43. Michael Power, ORganized Uncertainty: Designing a World of Risk MANAGEMENT 53-56 (2007).

44. Andrew Barry, Ethical Capitalism, in Global Governmentality: Governing INTERNATIONAL SPACES 195, 203-207 (Wendy Larner \& William Walters eds., 2004).

45. Jane Lister, Green Shipping: Governing Sustainable Maritime Transport, 6 GLOBAL POL'Y 118, 118 (2015). 
polycentric governance with regulators and regulated operating at different levels and in mixed, interactive, and interdependent forms. ${ }^{46}$

Prior to the emergence of modern states, the maritime industry was largely free from regulation that placed restrictions on trade and the transportation of goods. Once state and interstate regulations began to shape the movement of goods, these regulations were founded on more than two thousand years of rules that had developed from within the maritime industry itself, just as most of the standard practices later to be backed by modern state law were developed by maritime business. ${ }^{47}$ The practices from the late nineteenth century and onward were especially influential in bolstering business self-regulation within the maritime industry. Such self-regulation was then endorsed by the states. International conferences to prevent collisions and enhance safety of life, among other things, made the initial steps for international conventions to come. ${ }^{48}$ The surge of private classification societies that established and verified compliance with technical standards for the construction and maintenance of vessels and the rise of insurance companies suggested growing concern with the risks associated with massive transportation on the sea. Organizations like the International Chamber of Shipping; the International Association of Classification Societies; the International Association of Ports and Harbors; and the Baltic and International Maritime Council (BIMCO), which represents ship-owners controlling today the majority of the world's tonnage, are all important actors in governing the maritime industry. With the creation of the United Nations, the first intergovernmental body to emerge addressing maritime affairs was the Inter-Governmental Maritime Consultative Organization (IMCO), later to become the International Maritime Organization (IMO) in 1982.

The maritime industry has experienced an intensification of economic competition over the years. But this has neither diminished the traditional influence of corporate players in the industry nor reduced state-driven regulation. Forms of regulation that mix the state and non-state in ways that emphasize "proactive compliance" with

46. See Michael Bloor et al., Room for Manoeuvre? Regulatory Compliance in the Global Shipping Industry, 22 Soc. \& LEGAL STUD. 171 (2013); Michael Roe, Multi-level and Polycentric Governance: Effective Policymaking for Shipping, 36 MAR. POL'Y \& MGMT. 39 (2009); Helen Sampson \& Michael Bloor, When Jack Gets out of the Box: The Problems of Regulating a Global Industry, 41 SocIOLOGY 551 (2007); Elizabeth DeSombre, Globalization, Competition, and Convergence: Shipping and the Race to the Middle, 14 GLOBAL GOVERNANCE 179 (2008).

47. Braithwaite \& Drahos, supra note 36, at 418-37; A. Claire Cutler, Private Authority in International Trade Relations: The Case of Maritime Transport, in PRIVATE AUTHORITY AND INTERNATIONAL AFFAIRS 283 (A. Claire Cutler et al. eds., 1999).

48. BRAithWAite \& Drahos, supra note 36 , at 420. 
existing legal frameworks have been evolving. ${ }^{49}$ For example, a ship must be registered with a national registry, a "flag state," which makes it subject to that state's regulations wherever it moves. ${ }^{50}$ Historically, it was required that a vessel should fly a national flag, and be owned by nationals, to ensure a close economic and operational connection between the vessel and the state where it is registered. For many decades, however, vessel owners and operators, in order to escape regulatory standards set by states through the IMO and to save operational costs and taxes, have transferred to state jurisdictions offering "open registries" with lax or absent regulatory enforcement. The process has been termed "flagging out" and operating under "flag of convenience." As DeSombre has argued, ship owners "have been willing to take advantage of the demonstrated willingness of some states to lower standards to attract ship registrations, with a dramatic migration of ship registration to open registries, resulting in at least initial lowering of environmental, safety, and labor standards." 51

But regulatory interventions to improve the maritime industry in these respects have taken place, such as the Port State Control system. The system was established in the early 1980s, with a specific view to enforce international regulation on ship operators who were avoiding regulations by "flagging out" to commercial registries. Within this framework, regional alliances of port states deploy a common inspection and surveillance methodology on foreign-flagged ships, including a reporting regime, and the results are made public. Port State Control officers inspect vessels to check on compliance with international standards, which their home state has ratified, and they may require deficiencies in compliance to be rectified. Serious deficiencies can lead to vessel detention, consequent extra berthing fees, and lost business. ${ }^{52}$ The control systems, including the reporting regime that has been established to make ship performance "transparent," exemplify how states and public regulatory interventions interact with corporate actors to create incentives for businesses to proactively comply with international standards. ${ }^{53}$ But this system, as well as the constellation

49. Sampson \& Bloor, supra note 46 .

50. It is a main principle in international law "that jurisdiction over a vessel on the high seas resides solely with the state to which the vessel belongs. A second principle, which is corollary of the first, is that vessels using the high seas must possess a national character. The concept of the flag in maritime law and practice is virtually synonymous with ship registration.” Proshanto K. MUKHERJEe \& MARK BROWNRIGG, FARTHING ON InTERnATIONAL SHIPPING 199, 205 (Maximo Q. Mejia, Jr. \& Jens-Uwe Schröder-Hinrichs series eds., 4th ed. 2013).

51. DeSombre, supra note 46 , at $179,180$.

52. Sampson \& Bloor, supra note 46, at 551, 556.

53. DeSombre, supra note 46, at 179, 190. 
of actors involved in the local management of ports and customs, not to forget the personnel and charterers of vessels, also provides an interesting microcosm for the exploration of maritime actors in corruption. The next section analyzes this issue, as well as the main characteristics of the post-crime interventions by states.

\section{CORRUPTION AND POST-CRIME INTERVENTIONS}

Research on corruption in the maritime industry is scarce and typically narrowly focused on the phenomenon in relation to trade costs and the operation of ports and customs authorities. ${ }^{54}$ Under-resourced customs services and weak institutions in ports and at borders can result in discretionary powers and opportunities for customs officials, port operators, port personnel, and other agents to extract "special" payments from ships. Sometimes port officials and corporations collude to share the rents generated-for example, when a bribe is paid to evade tariffs, or to have authorities turn a blind eye to illegal labor substandard safety practices on board; at other times, port officials coerce corporations into paying additional fees-cfacilitation payments"- to clear the ship and its goods through the port without unnecessary delays. ${ }^{55}$ A report by Control Risks, a global consultancy, notes that it is not uncommon for port officials to request payments for influencing a port-state-control report on a given vessel's condition, which undermines the inherent goal of transparency in the reporting regime of the Port State Control system. ${ }^{56}$ Moreover, one recent study of the relationship between seafarers and shore-side personnel found that while in some areas of the world, especially Europe, Japan and the United States, the vulnerability of vessels and seafarers is not generally exploited by port personnel; in other parts of the world "such exploitation is routine and takes the form of demanding 'gifts' of produce and cash."57 Seafarers entering ports find themselves exceptionally

54. See, e.g., Sandra Sequeira \& Simeon Djankov, Corruption and Firm Behavior: Evidence from African Ports, 94 J. INT'L ECON. 277 (2014) (investigating the impact of corruption in ports on firm-level trade costs in the context of import shipping).

55. See id. at 277; see also Sandra Sequeira \& Simeon Djankov, Trade Costs and Corruption in Ports, PORT TECH. INT'L, Spring 2012, at 34-35.

56. See CONTROL Risks, CORRUPTION IN EUROPEAN PORTS 2, https://www.controlrisks .com/ /media/Public\%20Site/Files/Reports/Corruption\%20in\%20European\%20Ports.pdf (last visited Oct. 8, 2017).

57. Helen Sampson et al., The Relationship Between Seafarers and Shore-side Personnel: An Outline Report Based on Research Undertaken in the Period 2012-2016, SEAFARERS INT'L RESEARCH CTR. 2 (Apr. 2016), http://orca.cf.ac.uk/92378/1/The\%20rela tionships\%20between\%20seafarers\%20and\%20shore-side\%20personnel.pdf. 
vulnerable as targets for extortion and exploitation in part because they are working under time-pressure and stress. As one seafarer explains:

Gifts have become an integral part of ensuring good interaction onboard. It guarantees, in some ports, early approval of documents. It makes life easier for people on the ship because if gifts are not provided to these people delays could happen. For example, according to a friend of mine who was chief mate on this ship, the quarantine inspectors came and inspected the galley and the food storage. After that, they went to the captain and asked for some cigarettes and wine. The captain refused to give them anything. He said that he did not give anything to anybody. As a result of that, the ship was arrested for some supposed deficiencies. They were fined more than 100,000 USD because they supposedly found expired products. The company paid the amount, they had no choice, and the ship was blacklisted while everything was being rectified. So sometimes it is much better to give gifts. ${ }^{58}$

This focus on the relationship between port personnel and seafarers, although extremely important, considers petty corruption in the maritime industry. How such relatively small transactions are implicated in wider social relationships, including grand corruption schemes, remains to be researched. For example, the use of flag of convenience allows ship owners to register their ships under a foreign flag, typically in a country in need of currency and capable of providing anonymity, because the ships fail to meet the standards of the owner's country. While flag of convenience is not itself illegal, the system can be used to facilitate tax evasion, money laundering, and other illegal exchanges in which various forms of corruption may have been at play. Grand corruption in the maritime industry may even be entangled with fraud, illegal financing of political parties, and state capture as seen in other sectors, such as in the extractive operating in areas of limited statehood. ${ }^{59}$

After all, this reflects that corporations, much like states, are not "unitary actors." Corporations are highly complex organizational

58. Id. at $14-15$.

59. Charles McPherson \& Stephen MacSerraigh, Corruption in the Petroleum Sector, in The Many Faces of Corruption: Tracking Vulnerabilities at the Sector Level 191 (J. Edgardo Campos \& Sanjay Pradhan eds., 2007) (characterizing corruption in oil sector in four distinctive ways and describing relevant actors involved therein). 
arrangements with multiple activities, personnel, and links to suppliers and others operating transnationally across different sectors and industries, enhancing the likelihood of corruption in their global supply chains. ${ }^{60}$ It is well documented in literatures on corruption and TOCs that firms and especially individuals and groups of staff are involved in dense networks with agents, intermediaries, local state officials, and political leaders through whom monetary and other services can be negotiated in exchange for deals and concessions. ${ }^{61}$ Some of these transactions include vast sums of money in labyrinth-like, opaque exchanges mediated by banks and shell companies "off shore," as evidenced in the recent and massive leaks of the so-called "Panama Papers" and "Paradise Papers", ${ }^{62}$ just as they can involve mechanisms of reciprocity and loyalty based on friendship, kinship, and patronage. ${ }^{6}$ Thus, corruption undoubtedly has many more faces in the maritime industry than those relating to the operations in ports and customs. A thorough analysis of the issue would not only require a solid, interdisciplinary approach to the exploration of corruption, ${ }^{64}$ but also a comprehensive investigation of the entanglement of the maritime industry in the global political economy, including its potential links to governmental agencies and illicit private authority in areas of limited statehood, such as TOCs.

The rise in maritime activities and traffic globally has exposed companies transporting cargo to corruption as they expand deeper into emerging markets in areas of limited statehood. Given this development, how has corruption in the maritime industry been approached by states? The United States has increasingly taken postcrime enforcement actions through the U.S. Department of Justice (DOJ) and Securities and Exchange Commission (SEC). For example, in

60. See generally Blake E. Ashforth et al., Introduction to Special Topic Forum: Reviewing Organizational Corruption, 33 ACAD. MGMT. REV. 670 (2008) (explaining the importance of understanding corruption in the organizational context).

61. See, e.g., Williams, supra note 15, at 176-77 (explaining how corruption involves exchange relationships between criminal organizations and politicians).

62 See, e.g., Sasha Chavkin, More Questions Circle Wilbur Ross' Ethics as GAO Investigation Requested, INT'L CONSORTIUM INVESTIGATIVE JOURNALISTS (Nov. 16, 2017), https://www.icij.org/investigations/paradise-papers/questions-circle-wilbur-ross-ethics-gaoinvestigation-requested/; Nordea Shipping Loans Caught Up in 'Paradise Papers' Spotlight, FAIRPLAY, https://fairplay.ihs.com/commerce/article/4293811/nordea-shippingloans-caught-up-in-\%E2\%80\%98paradise-papers\%E2\%80\%99-spotlight (last visited Jan. 29, 2018); Cooley \& Sharman, supra note 4.

63. See Giorgio Blundo et AL., Everyday Corruption and the State: Citizens and Public OfFicials in AFricA (Giorgio Blundo \& Jean-Pierre Olivier de Sardan eds., Susan Cox trans., 2006); Cooley \& Sharman, supra note 4, at 736-746.

64. See David Jancsics, Interdisciplinary Perspectives on Corruption, 8 Soc. CoMPASS 358, 359-65 (2014); Williams, supra note 15. 
2010, the Swiss Panalpina World Transport and its U.S. subsidiary, Panalpina Inc., admitted to having paid bribes totaling at least 27 million USD to foreign government officials on behalf of customers for customs clearance in Angola, Azerbaijan, Brazil, Kazakhstan, Nigeria, Russia, and Turkmenistan. The DOJ charged Panalpina with violating the anti-bribery provisions of the FCPA, and with aiding and abetting customers in violating the same provision. The company was required to pay a criminal fine of seventy million USD and to implement an enhanced compliance program. Some of the company's customers admitted that they approved of or condoned the improper payments made on their behalf in Nigeria. These payments were recorded as legitimate business expenses in their books and records. ${ }^{65}$

Moreover, there has been a broadening in the scope of anticorruption legal systems to target facilitation payments. In some countries and sectors, facilitation payments are made to government officials to "grease" or speed up bureaucratic processes and access services the payer is lawfully entitled to. Facilitation payments were traditionally exempted in anti-corruption legislations, such as the FCPA and the OECD Convention on Combating Bribery of Foreign Public Officials in International Business Transactions of 1997. However, in 2009 the OECD issued a recommendation to member states to prohibit or discourage facilitation payments. 66 Further, in 2010 the British government passed the Bribery Act (UKBA), which entered into force in 2011 and drew on the extraterritorial principle like the FCPA. Unlike the aforementioned legislations, the UKBA includes facilitation payments in its definition of bribery. This means that a payment made by a shipping officer to a customs official to induce or expedite a standard procedure is now prohibited and can be caught under the UKBA. It is important to note, however, that bribery and facilitation payments are more than just subject to post-crime interventions: the UKBA also regards the failure to take adequate procedures against bribery and facilitation as a corporate offence. ${ }^{67}$ This observation takes us to the next step of the analysis, which explores how maritime players have begun to engage in pre-crime policing through the establishment of collective action initiatives, as well as how their activities are interacting with public rulemaking.

65. William F. Pendergast et al., Quarterly FCPA Report: Fourth Quarter 2010, PAUL HASTINGS 4 (Jan. 2011), https://www.paulhastings.com/docs/default-source/PDFs/1793.pdf.

66. Org. for Econ. Co-operation and Development [OECD], Recommendation of the Council for Further Combating Bribery of Foreign Public Officials in International Business Transactions, I VI (Nov. 26, 2009), https://www.oecd.org/daf/anti-bribery/441 76910.pdf.

67. Bribery Act 2010, c. 23, § 12 (U.K.); Slager, supra note 11, at 369-70. 


\section{Pre-Crime: The Maritime Anti-Corruption Network (MACN)}

The MACN dates back to 2010, when maritime industry competitors began to cooperate informally in light of complaints from their captains and seafarers being extorted by port and customs personnel, the growing FCPA enforcement, and the launch of the UKBA. The arrangement quickly attracted the attention of local and national authorities, customers and port agents, and the UNDP and Transparency International. Thus, an official launch took place in 2012. ${ }^{68}$ Soon thereafter members began to put the MACN's logo on their websites and refer to the new initiative at conferences. A workspace for members only was created to facilitate the sharing of information, and in 2014 an online public platform was established. By 2017, the MACN had 90 members (including the largest members in the industry), which were divided into regular and associate members consisting of vessel owners and operators, companies or incorporated organizations in the maritime industry, ports and terminal operators, shipping agents, freight forwarders, associations, and others. Some members already participated in existing cross-sector initiatives like the UN Global Compact, whose Principle 10 declares that "Businesses should work against corruption in all its forms, including extortion and bribery,"69 and in the industry-oriented initiative Extractive Industries Transparency Initiative (EITI), whose aim is to promote "the open and accountable management of natural resources" to avoid the grand corruption characteristic of extractive industries. ${ }^{70}$ In comparison to the mentioned arrangements, the MACN is business-driven and has a narrower focus on petty corruption, such as bribery and facilitation payments in ports and customs.

The MACN has set prerequisites for and coordinates member activity; allocates resources generated by membership fees and other funding; trains and monitors corporate and non-corporate activity; develops and shares archives, databases and internal reporting; engages in and cooperates with other stakeholders; and communicates in public. While the arrangement incorporates the classical organizational elements of membership, hierarchy, rules, monitoring, and sanctions as spelled out earlier, ${ }^{71}$ the degree of completeness and significance of

68. See About MACN, MAR. ANTI-CORRUPTION NETWORK, www.maritimeacn.org/about-macn/ (last visited Oct. 8, 2017).

69. The Ten Principles of the UN Global Compact, UniTED Nations GLoB. CompaCt, https://www.unglobalcompact.org/what-is-gc/mission/principles (last visited Oct. 8, 2017).

70. See Who We Are, Extractive Indus. TransParency Initiative, https:/eiti.org/ who-we-are (last visited Oct. 8, 2017).

71. Ahrne \& Brunsson, supra note 38. 
these elements in the MACN's daily work remains to be studied in more detail, although the arrangement appears considerably more formalized and focused than other collective arrangements in anti-corruption operating transnationally (even though the word 'network' appears in its name). Its formal governance structure comprises a member-elected steering committee; an annual member meeting; and a secretariat consisting of one full-time program director and five part-time staffs 72 who manage and coordinate the activities and work in close coordination with the steering committee on the overall strategy, and with members on the more specific activities. The work carried out by the secretariat includes preparatory research for collective action in specific regions and the coordination of activities, outreach, and communication. The MACN is guided by a "strict antitrust policy,"73 with membership conditioned on payment of a fee as well as the honoring of other commitments.

In its public communication, the MACN emphasizes the positive reputational effects and greater impact on the fight against corruption following from membership. Access to the knowledge resources generated by the established information infrastructure is portrayed as a benefit to members. Members also benefit from the opportunity to "[u]se the MACN logo as a powerful mechanism to signal [their] commitment to the MACN Anti-Corruption Principles, which are modeled on the requirements of the U.K. Bribery Act . . . . By participating in MACN collective action, [members] have a greater impact in alleviating a fundamental bottleneck of trade and development than by acting alone." 74 Moreover, should a member be caught in a corruption related event under the UKBA, membership can potentially help relieve legal punishment as it serves as a signal to law enforcement authorities that adequate preventive procedures should be in place, or at least, that the member is working on it. The fact that members refer to MACN on their websites suggests there is potential to flag member commitment to anti-corruption and help MACNs as a collective action initiative in its efforts at gaining global public recognition. For example, when MACN won the "TRACE Innovation in Anti-Bribery Compliance Award" for its collective anti-corruption

72. The Secretariat, MAR. ANTI-CORRUPTION NETWORK, www.maritime-acn.org/thesecretariat (last visited Nov. 11, 2017).

73. See MACN Members, MAR. ANTI-CORRUPTION NETwORK, http://www.maritimeacn.org/macn-members/ (last visited Oct. 8, 2017).

74. Why Join MACN, MAR. ANTI-CORRUPTION NETWORK, http://www.maritimeacn.org/join/ (last visited Apr.10, 2018). 
efforts, it was mentioned on several members' websites. ${ }^{75}$ TRACE International presents itself as "a globally recognized anti-bribery business organization and leading provider of third party risk management solutions" and has been operating in the global anticorruption industry for more than a decade. ${ }^{76}$

The MACN is facilitated by Business for Social Responsibility (BSR), which is a nonprofit organization funded by corporate membership fees based on a member company's total consolidated annual revenues and grant contracts with multilateral and bilateral donor organizations. BSR works with businesses "to create a just and sustainable world." 77 In its more specific work with the MACN, it seeks to facilitate the implementation of "seven anti-corruption principles" in the MACN member companies. These principles include (i) the creation of a compliance program designed to address the risks associated with the company's business; (ii) proportionate anti-corruption procedures, which prohibit all forms of corruption and "give specific guidance on facilitation payments with the ultimate aim of their elimination"; (iii) the assessment and documentation of internal and external corruption risks; (iv) training of and communications of policies and procedures to employees; (v) monitoring and internal controls, which includes mechanisms "designed to prevent and detect incidents of bribery, facilitation payments and other forms of corruption through appropriate monitoring and auditing protocols"; (vi) reporting, discipline, and incentives for employees to ask questions and report concerns. This includes incentives for proper behavior and, where necessary, "enforced through discipline for improper behavior"; and (vii) the conduct of riskbased due diligence, which means scrutinizing "third parties and business partners." 78 In addition to member adherence to these principles, the lessons learned and best practices must also be shared. A number of mechanisms have been set up, such as secure incident reporting channels.

The MACN is characterized by its focus on "hot spot" regions and localities. This focus resonates what the organization terms a "Theory of Change," which assumes "two key levers for change." While the first lever seeks to "strengthen[] members' internal anti-corruption

75. MACN Wins Innovation in Anti-Bribery Compliance Award 2015, J. LAURITZEN, CORP. RESP. (Apr. 8, 2015), http://www.j-l.com/macn-wins-innovation-anti-briberycompliance-award-2015.

76. Advancing Commercial Transparency Worldwide, TRACE InTERnATIOnAL, https:// www.traceinternational.org/home (last visited Nov. 14, 2017).

77. About Us, BUs. FOR Soc. RESPONSIBILITY, https://www.bsr.org/en/about (last visited Oct. 8, 2017).

78. MACN's Work, MARITIME ANTI-CORRUPTION NETWORK, http://www.maritimeacn.org/macn-work/ (last visited Nov. 14, 2017). 
management practices and programs," the second lever aims to "contribute to improvements in the external operating environment, recognizing that, in the absence of changes in the operating environment, internal improvements are unlikely to yield the desired benefits." 79 In its work in "hot spot" regions, the MACN seeks to engage local and national governmental agencies and other key actors in the collaboration on mitigating the risk of bribery and corruption. This can imply seeking official governmental support for the actions defined within projects, such as the one in Nigeria referred to in the beginning of the article. 80 However, similar initiatives have recently been developed in other "hot spots." For example, in 2014, the MACN launched a project in the port of Rosario, Argentina, in collaboration with a local law firm, based on reports from members that a large proportion of ship inspections by local authorities are resolved through bribery demands. There was not a local, trustworthy accountability mechanism to enable members to report these demands. To tackle corruption of this kind, the MACN engaged with other local actors, including the responsible ministry. The project has resulted in reforms of the current inspections system, new government regulation, and the establishment of an e-governance system requiring all inspections to be electronically recorded. In 2015, the MACN launched a similar collective action project in Indonesia, supported by UK Foreign and Commonwealth Office and in partnership with a local NGO. The project's aim is to improve and address corruption risks in import and export operations and has resulted in a number of concrete reform actions. ${ }^{81}$

In all, while much activity revolves around the expectation that collective action at the operational level can be incorporated into individual member companies' risk management and compliance activities, it is also clear that the MACN seeks to induce changes into the operating environment, especially by seeking to prevent governments' demands for bribes through local collective action in hot spot areas of limited statehood. The development of MACN suggests that legislation and public regulatory efforts in anti-corruption at various levels have had an imprint on how maritime industry players organize around this issue. The work being done on anti-corruption

79. MARItime ANTI-CORRUPtion NETWORK, IMPACT REPORT 3 (2016), https://static1.squarespace.com/static/53a158d0e4b06c9050b65db1/t/590b376eff7c500c50fb 8394/1493907359499/MACN+Impact+Report+2016_Web_Pages.pdf.

80. Bureau of Public Procurement, supra note 2.

81. See generally Martin Benderson, The Maritime Anti-Corruption Network: Tackling Corruption through Collective Action, 3 J. SustainaBle MoBILITY 94 (2016) (examining MACN's collective action projects in Indonesia and other countries). 
amounts to proactive and preventive policing of certain forms of corruption in areas of limited statehood where corruption is endemic and anti-corruption enforcement actions on the part of state agencies are traditionally considered weak.

\section{Discussion And Concluding Perspectives}

In recent years TNCs have developed collective action initiatives targeting corruption. This article analyzed the broader contours of this development and studied a recent collective action initiative driven by TNCs in the maritime industry in more depth. Elaborating on insights from theories of private authority, studies of governmentality, and criminology, it also asked the general question as to what significance such TNC practices can have in relation to the policing of corruption and with respect to the organization of public and private authority in the global political economy.

The analysis has produced a number of insights. First, even though the core of my focus has been on a collective action initiative emerging from one particular industry, it is clear that anti-corruption efforts today are polycentric. Individual states operate through an increasingly transnational, enforcement regime spearheaded by the FCPA and its extraterritorial features and more recently the UKBA. Some TNCs are members of collective action initiatives that mobilize the language of the mentioned legislations and use it as a strategic resource ${ }^{82}$ to generate social meaning and signification, which come to shape social actors and their activities. ${ }^{83}$ Collective action initiatives address internal company issues and help establish compliance and risk management systems throughout supply chains, but they can also, as in the case studied here, work on changes to the external institutional environments where members operate. Collective action initiatives in anti-corruption are technically "voluntary." Even if the companies signing up for collective initiatives do not consider the risk of getting caught in the anticorruption legal web as particularly high, opportunities and benefits might be harvested by voluntarily joining in. Flagging participation in collective action initiatives might help improve reputation and relieve punishment in case of violations, and as such, have regulatory effects overall. ${ }^{84}$

82. Slager, supra note 11 , at 379 .

83. Rajkovic, supra note 35, at 3-6; Garland, supra note 31, at 182-193; Goldmann, supra note 35 , at $335,338,366$.

84. See generally Terry O'Callaghan, Disciplining Multinational Enterprises: The Regulatory Power of Reputation Risk, 21 GLOBAL SOC'Y 95 (2007) (discussing the rise in incidence of and motivations behind corporate reputational protection). 
Second, as corporate collective action initiatives in anti-corruption do not unfold in isolation from governmental regulation but rather emerge from the interactive dynamics shaping rationalities and techniques of lawmaking, enforcement, and corporate self-governing, it would be misleading to regard them as reflecting a relatively autonomous kind of private authority. These observations do not detract from the more general and valuable insights made in studies of private authority, especially the emphasis on the growing role non-state actors and particularly corporations have in the transnational governance of an increasing range of issues (i.e., anti-corruption). But that development does not entail a shift from public toward private authority, but rather the pluralization and temporal diversification of anti-corruption work, as captured in this article through the concept of policing. Collective action initiatives have a pre-crime scope and display logic of anticipatory action cast in the language of "corruption risk." The classification of corruption as a risk becomes justification for action in the here and now to "prevent, mitigate, adapt to, prepare for or preempt." 85 The identification, sorting, and management of "hot spots" typically located in areas of limited statehood, including populations and institutions, together with the introduction of information exchange in shape of reporting systems, can be seen as significant complementary techniques to the state-driven modes of post-crime, which will most likely address only a microscopic part of the activities formally classified as "corrupt." The classification of corruption as a risk has co-developed with the anti-corruption industry, which enrolls state, non-state, and hybrid actors in a globalizing network disseminating anti-corruption language and values, ${ }^{86}$ including blacklists of corrupt companies and perception-based rankings of most corrupt countries. These can be aggregated in larger databases, all of which can be used in due diligence exercises potentially subject to so-called big data analytics to reduce uncertainties and predict new trends. ${ }^{87}$ These developments in no way ensure a smooth implementation of anti-corruption ideals into everyday organizational practices. Nor do they imply a globalizing "normalization" process. Still, they are connected to the proliferation of pre-crime and its emphasis on intelligence, and they resonate well with

85. Anderson, supra note 39, at 777, 778-779; MCCULLOCH, \& WILSON, supra note 40.

86. Hansen, supra note 11, at 251; Sampson, supra note 11; Koehler, supra note 11 , at 558.

87. Bill Olsen, Dan Reynolds, \& Alex Koltsov, 5 Using Data Analytics to Meet THE GOVERnMENT's ANTI-CORRUPTION COMPLIANCE EXPECTATIONs (2016), www.grant thornton.com/ /media/content-page-files/advisory/pdfs/2016/Data-Analytics-Meet-GovtAnti-Corruption-Compliance.ashx (note that The FCPA Report has since been renamed to The Anti-Corruption Report). 
the politics of transparency and surveillance so characteristic of our times. ${ }^{88}$

Finally, the capacity of corporate collective action initiatives to operate as centers of calculation that govern at a distance deserves much more attention in future research. For example, while our knowledge about the characteristics of collective action initiatives and their potential impact on high-level policy-making and in business circles is expanding, ${ }^{89}$ very little is known about the more specific operations of corporate collective action initiatives throughout value chains and especially in the "hot spots" of areas of limited statehood. This begs the following question: in what sense and to what extent might collective action initiatives addressing corruption pre-crime operate as "functional equivalents" 90 for (absent) state driven law enforcement post-crime in such contexts? Moreover, it is important to analyze the implications of corporate attempts at preventing corruption when it comes to the possible resistance emerging at the local level. Once local public agencies are "cleaned up," and long-lasting informal networks of exchange and patronage can no longer function as systems of redistribution amongst local public officials the way they did before corporate collective action on location, what happens next? Such questions, hopefully to be taken up in future research, are among the many that spring into mind once we begin to empirically explore and theorize the ambiguous roles of TNCs in anti-corruption collective action in multiple contexts.

88. McCulloch, \& Wilson, supra note 40; Hans Krause Hansen, Numerical Operations, Transparency Illusions and the Datafication of Governance, 18 EUR. J. SOC. THEORY 203, 216-222 (2015). See generally Hans Krause Hansen \& Morten Hove Tang-Jensen, Making up Corruption Control: Conducting due Diligence in a Danish Law Firm, 15 EPHMERA: THEORY AND POL. ORG. 365 (examining corruption control through the use of anticorruption due diligence in a Danish law firm).

89. See Berta van Schoor \& Christoph Luetge, Can Cooperation Prevent Corruption? Effects of Collective Commitment in Sector-Specific Coordinated Governance Initiatives on Anti-Corruption Strategies, BASIL INST. OF GOVERNANCE 5 (Oct. 2016), https://collectiveaction.com/sites/collective.localhost/files/conference/icca-2016/collective-action-conferencevan_schoor-luetge_0.pdf.

90. Börzel \& Risse, supra note 21. 